\title{
Sosialisasi Pendampingan Orang Tua terhadap Proses Belajar Anak selama Masa Pandemi Covid 19
}

\author{
Socialization of Parents' Assistance to Children's Learning Process during the Covid 19 \\ Pandemic
}

\author{
Laelia Nurpratiwiningsih ${ }^{1}$, Novi Yuliyanti ${ }^{2}$, Prasetyo Yuli Kurniawan ${ }^{3}$ \\ ${ }_{1,2}^{1,2}$ endidikan Guru Sekolah Dasar, Fakultas Keguruan dan Ilmu Pendidikan, Universitas Muhadi \\ Setiabudi, Indonesia \\ ${ }^{3}$ Pendidikan Bahasa dan Sastra Indonesia, Fakultas Keguruan dan Ilmu Pendidikan, Universitas Muhadi \\ Setiabudi, Indonesia \\ e-mail: ${ }^{1}$ laelian.np89@gmail.com, ${ }^{2}$ noviyuliyanti61@gmail.com, ${ }^{3}$ prasetyoyulikurniawan@gmail.com
}

\begin{abstract}
Abstrak
Pandemi covid 19 memberikan dampak pada beberapa bidang di dunia. Salah satunya adalah bidang pendidikan. Hal ini terlihat pada pembelajaran yang dilakukan oleh peserta didik yang awalnya tatap muka menjadi pembelajaran yang dilakukan di rumah. Dengan adanya pembelajaran di rumah maka perlu adanya sarana dan prasarana yang memadai serta pentingnya peran orang tua dalam kegiatan pembelajaran tersebut. Namun kenyataannya bahwa masih kurang adanya sarana dan prasarana yang mendukung dalam kegiatan pembelajaran serta sibuknya aktivitas orang tua dalam bekerja. Berkaitan dengan hal tersebut, maka perlu adanya sosialisasi pendampingan peran orang tua terhadap proses belajar anak selama masa pandemi covid 19. Sasaran dalam pengabdian ini adalah orang tua yang memiliki anak usia sekolah dan guru TK serta guru SD. Metode yang digunakan dalam pelaksanaan kegiatan adalah observasi, studi pustaka dan pendampingan. Pendampingan dilakukan melalui kegiatan ceramah dan tanya jawab bagi peserta pendampingan. Hasil menunjukkan bahwa orang tua, guru SD dan guru TK dapat mengikuti sosialisasi terkait dengan pembelajaran daring dengan baik dan tertib dan dapat memahami materi pembelajaran daring serta dapat menerapkan kegiatan pembelajaran daring di rumah.
\end{abstract}

Kata kunci-Pendampingan, Proses Belajar, Covid 19

\begin{abstract}
The covid 19 pandemic has an impact on several areas of the world. One of them is the field of education. This can be seen in the learning done by students who initially face-to-face into learning done at home. With home learning, there needs to be adequate facilities and infrastructure and the importance of the role of parents in these learning activities. But the reality is that there are still lack of supporting facilities and infrastructure in learning activities as well as busy activities of parents in work. Related to this, it is necessary to socialize the role of parents to the learning process of children during the covid 19 pandemic. The targets in this service are parents who have school-age children and kindergarten and elementary teachers. The methods used in the implementation of activities are observation, literature studies and mentoring. Mentoring is carried out through lectures and question and answer activities for mentoring participants. The results showed that parents, elementary teachers and kindergarten teachers can follow socialization related to online learning in a good and orderly manner and can understand online learning materials and can implement online learning activities at home.
\end{abstract}

Keywords-Mentoring, Learning Process, Covid 19

\section{PENDAHULUAN}

Covid 19 merupakan pandemi bagi masyarakat yang berbahaya di dunia. Hal ini dapat menyebabkan kematian bagi masyarakat yang terkena virus tersebut. Selain itu, covid 19 ini juga dapat membawa dampak bagi masyarakat di dunia. Dampak tersebut lebih kepada hal negatif. Seperti halnya pada bidang ekonomi, dimana hal ini dapat memberikan dampak pada perputaran perekonomian di dunia. Kegiatan perekonomian sebagian besar berhenti untuk sementara sehingga berdampak pada penghasilan masyarakat. 
Dampak pandemi covid 19 pada bidang ekonomi yaitu membawa pasar ke arah yang lebih rendah dari sebelumnya. Analisis sensitivitas menjelaskan bahwa lambatnya kegiatan ekonomi global pada saat ini sangat berdampak pada pertumbuhan pereekonomian Indonesia(Gikas \& Grant, 2013). Kegiatan perekonomian tersebut dialami oleh semua kalangan masyarakat di Indonesia. Pendapatan yang diperoleh berkurang, tidak seperti sebelum terjadinya pandemi. Namun hal ini juga dapat menimbulkan adanya kreativitas bagi masyarakat dalam mengelola perekonomian.

Salah satunya adalah dengan adanya pemanfaatan e-commerce. Hal ini terlihat pada penerapan teknologi seperti website yang mampu membantu dalam promosi dan pemasaran kendang jimbe. Selain itu, pada sistem B2C juga mampu diterapkan dalam proses pemasaran karena dapat mengakomodir konsumen pada jenis dan spesifikasi kendang jimbe tersebut(Harliana et al., 2020). Dengan adanya pemanfaatan e-commerce dapat memperbaiki perekonomian masyarakat. Namun, hal ini juga harus diimbangi dengan kemampuan yang dimiliki oleh masyarakat dalam mengelola hal tersebut.

Selain di bidang perekonomian, juga berdampak pada bidang pendidikan. Salah satunya adalah pada kegiatan belajar mengajar bagi peserta didik. Berdasarkan observasi menunjukkan pada kegiatan pembelajaran yang dilakukan oleh peserta didik di tingkat SD dan TK dilakukan pembelajaran daring. Namun, dalam pembelajarannya mendapatkan kendala dalam proses pembelajaran. Salah satunya adalah fasilitas sarana dan prasarana yang belum memenuhi. Seperti halnya peserta didik tidak memiliki handphone atau kuota internet. Permasalahan lain yang muncul apabila dilihat dari sumber daya manusianya, orang tua belum bisa maksimal dalam memberikan pengajaran kepada anaknya di rumah. Selain itu, kurang adanya kreativitas guru dalam mengajar dalam menangani pembelajaran daring.

Pembelajaran daring yang dilakukan oleh anak usia sekolah dasar kurang efektif. Hal ini dikarenakan oleh beberapa faktor, antara lain; belum semua peserta didik memiliki handphone, kuota dan internet yang dimiliki belum stabil, dan orang tua masih banyak yang masih sibuk bekerja (Putria et al., 2020). Sarana dan prasara sangat diperlukan peserta didik dalam melaksanakan pembelajaran daring. Selain itu, dari orang tua juga dapat memberikan hal yang positif bagi peserta didik.

Pembelajaran daring dapat dikatakan dalam pelaksanaanya perlu diberikan sebuah perhatian dari orang tua. Hal ini dikarenakan yang melaksanakan dan yang mengontrol kegiatan pembelajaran di rumah adalah orang tua. Mau atau tidak mau orang tua harus bisa mengendalikan anaknya dengan baik. Sehingga kegiatan pembelajaran di rumah dapat berjalan dengan lancar. Dukungan dari orang tua dapat berupa motivasi maupun ikut terlibat dalam kegiatan pembelajaran. Dukungan yang diberikan oleh orang tua dapat memberikan pengaruh kepada anaknya dalam belajar.

Pendampingan orang tua dalam proses belajar anak dapat dikatakan rendah. Hal ini terliat pada penyediaan fasilitas belajar anak di rumah, pengawasan kegiatan belajar di rumah, pengawasan penggunaan waktu belajar di rumah, pengawasan kesulitan yang dihadapi oleh anak dalam belajar dan menolong anak dalam mengatasi kesulitan dalam belajar (Ardiansyah \& Arda, 2020). Dengan adanya permasalah tersebut menjadi perhatian bagi orang tua dalam mendidik anaknya di rumah.

Berkaitan dengan hal tersebut, Pembelajaran daring merupakan solusi dalam menerapkan social distancing guna mencegah mata rantai penyebaran covid 19. Hal ini mengakibatkan adanya study from home (SFH). Pembelajaran yang dilakukan di rumah masing-masing. Dalam pembelarajaran daring ini perlu adanya sarana dan parasarana yang memadai. Dengan adanya pembelajaran daring ini menjadikan peserta didik menjadi mandiri (Handarini \& Wulandari, 2020). Pembelajaran mandiri yang dilakukan oleh peserta didik di rumah memberikan dampak positif dan negatif. Dapat memberikan dampak positif jika peserta didik melakukannya dengan baik. Namun sebaliknya, dapat memberikan dampak negatif jika peserta didik tidak melaksanakan kegiatan pembelajaran di rumah.

Pelaksanaan pembelajaran daring juga perlu diimbangi dengan adanya pemahaman karakter pada anak didik. Pemahaman karakter tersebut, antara lain; karakter religius, cinta kebersihan 
dan lingkungan, jujur, peduli dan cinta tanah air (Toharudin et al., 2020). Dengan adanya karakter ini dalam bersikap, berperilaku dan bertindak, maka akan terciptanya lingkungan yang aman dan sejahtera bagi sekolah, keluarga maupun masyarakat. Sehingga peserta didik dapat dengan mudah melakukan kegiatan pembelajaran.

Berkaitan dengan permasalahan-permasalahan tersebut, maka perlu adanya pemecahan masalah ataupun solusinya. Sehingga dalam pelaksanaannya dapat meminimalisir kendala-kendala yang ada. Oleh karena itu, perlu adanya solusi berupa "Sosialisasi Pendampingan Orang Tua terhadap Proses Belajar Anak selama Masa Pandemi Covid 19". Pada kegiatan ini membahas mengenai pendampingan pembelajaran daring bagi masyarakat di desa Cikuya, khususnya bagi orang tua yang memliki anak sekolah.

\section{METODE PELAKSANAAN}

Sasaran dalam pelaksanaan kegiatan pendampingan adalah orang tua yang memiliki anak usia sekolah baik pada tingkat PAUD, SD, SMP maupun SMA/ SMK. Hal ini diberikan kepada orang tua yang mengalami yang memiliki anak yang sedang melaksanakan kegiatan pembelajaran daring di rumah. Selain itu, sasaran diberikan kepada tenaga pengajar yaitu guru TK dan guru SD.

Tahapan pelaksanaaan kegiatan dilakukan dengan metode pendekatan yaitu tahap observasi, studi pustaka, pelatihan dan pendampingan. Tahapan ini sebagai solusi dalam permasalahan pengabdian masyarakat.

1. Observasi

Observasi dilakukan untuk mengetahui kebutuhan dan permasalahan yang ada di lapangan. Dalam hal ini permasalah yang terdapat pada desa Cikuya kabupaten Brebes. Hal ini berkaitan dengan kegiatan pembelajaran bagi anak usia PAUD, SD, SMP dan SMA/ SMK yang dilakukan di masyarakat.

2. Studi pustaka

Studi pustaka dimaksudkan sebagai literatur, seperti buku dan referensi lain untuk memperkuat materi yang digunakan dalam pendampingan. Studi pustaka berkaitan dengan pembelajaran daring sebagai acuan dalam proses pembelajaran.

3. Pelatihan

Pelatihan dimaksudkan untuk memberikan materi kepada peserta. Bagaimana peran orang tua dalam pembelajaran daring, hal ini lebih kepada memberikan motivasi kepada orang tua.

4. Pendampingan

Dalam hal ini pendampingan yang dilakukan menggunakan metode ceramah dan tanya jawab. Jadi, Proses pelaksanaan pengabdian masyarakat yang dilaksanakan berupa metode ceramah dan tanya jawab.

a. Metode ceramah

Metode ini merupakan penyajian informasi baik dilakukan secara formal. Materi disampaikan untuk memberikan informasi kepada orang tua, untuk memiminimalisir dari kesalahan dalam persepsi terkait dengan pembelajaran daring. Media yang digunakan adalah gambar dan video. Hal ini bertujuan agar orang tua lebih mudah dalam menyerap materi dan diharapkan dapat meningkatkan stimulus dan keinginan belajar bagi anaknya. Metode ini digunakan untuk membahas materi terkait pembelajaran daring. Selain itu, juga untuk memberikan motivasi kepada orang tua untuk memberikan semangat kepada anaknya untuk tetap melaksanakan pembelajaran di rumah. Tenaga pengajar juga diharapkan dapat memberikan motivasi kepada anak didiknya dan juga orang tua dari peserta didik tersebut.

b. Tanya jawab

Tanya jawab dilakukan untuk menambah pengetahuan dan wawasan bagi orang tua dan tenaga pengajar tentang pembelajaran daring. Tanya jawab ini merupakan metode yang komunikatif, dimana sebelum mengawali kegiatan, orang tua dan tenaga pengajar diberi 
stimulus terlebih dahulu. Selanjutnya orang tua dan tenga pengajar dilatih untuk menganalisis terkait dengan pembelajaran daring.

\section{HASIL DAN PEMBAHASAN}

Kegiatan pelaksanaan pengabdian kepada masyarakat ini berupa sosialisasi pendampingan orang tua terhadap proses belajar anak selama masa pandemi covid 19 di desa Cikuya kecamatan Banjarharjo kabupaten Brebes.

1. Proses Belajar Anak selama Masa Pandemi Covid 19

Pembelajaran yang dilakukan oleh masyarakat di desa Cikuya adalah pembelajaran yang dilakukan secara online dan tatap muka. Dapat dikatakan bahwa pembelajaran yang dilakukan adalah pembelajaran daring dan pembelajaran luring. Menurut peserta pengabdian menunjukkan bahwa pembelajaran daring dilakukan dengan menggunakan aplikasi jejaring sosial whatsapp. Hal ini dikarenakan aplikasi ini lebih mudah untuk digunakan oleh orang tua dan peserta didik. Sehingga dalam memanfaatkan dalam kegiatan pembelajaran lebih mudah untuk dipahami. Selain itu, bagi tenaga pengajar ini lebih mudah untuk mengoperasikan dan mengontrol kegiatan pembelajaran.

Sedangkan pada pembelajaran luring dilakukan setiap 2 kali dalam seminggu. Pembelajaran ini dimaksudkan untuk menyamakan persepsi peserta didik terkait dengan materi dan tugas yang harus dipahami. Materi dan tugas pembelajaran diberikan ketika tatap muka. Kemudian untuk tugas yang sudah diselesaikan di rumah dikumpulkan pada pertemuan selanjutnya. Persepsi merupakan pengorganisasian dan penginterpretasian terhadap stimulus pada indera sehingga menjadi sesuatu yang berarti dan adanya respon yang penting dalam diri individu (Walgito, 2010). Dalam hal ini berarti kegiatan pembelajaran memiliki nilai bagi peserta didik untuk melaksanakan pembelajaran sesuai dengan stimulus yang dimiliki dan meresponnya dengan mengerjakan tugas yang dimilikinya.

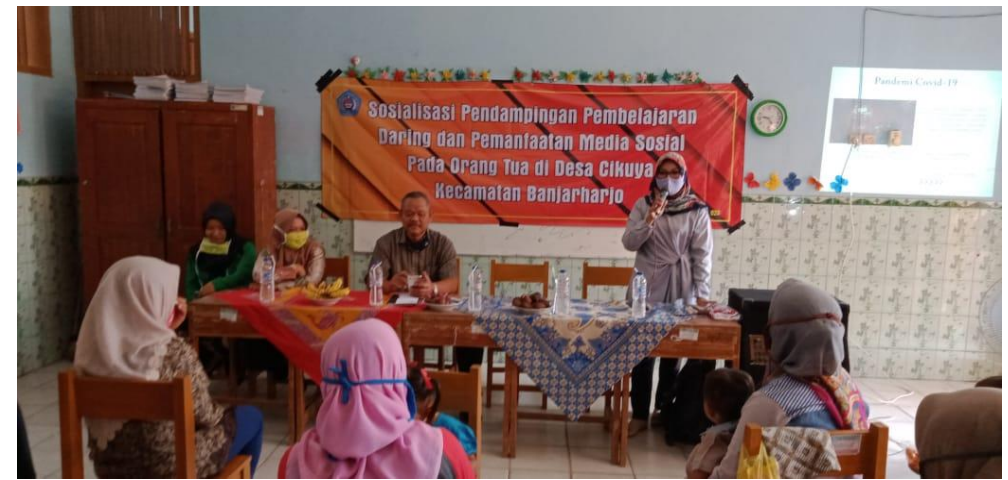

Gambar 1. Pemahaman Pembelajaran Daring

Pemahaman pembelajaran daring dapat ditujukan pada Gambar 1. Pelaksanaan pembelajaran daring membutuhkan adanya fasilitas sebagai penunjang, seperti; smartphone, laptop, tablet yang digunakan dalam mengakses internet(Gikas \& Grant, 2013). Kenyataan di lapangan menunjukkan bahwa sarana penunjang seperti smartphone sudah dimiliki oleh peserta didik. Namun, dalam pengoperasiaanya mendapatkan kendala. Kendala-kendala tersebut, seperti: smartphone tidak dipegang langsung oleh peserta didik, tidak stabilnya kuota dan tidak dapat mengoperasikan smartphone dengan baik. Dengan adanya kendala tersebut pembelajaran daring kurang maximal. Sehingga perlu adanya pembelajaran luring, yang mana tatap muka ini digunakan dalam menyamakan persepsi terkati pembelajaran yang sedang berlangsung. Kesibukan orang tua juga menjadi kendala dalam pelaksanaan pembelajaran daring di rumah. Padahal peran orang tua sangat penting dalam kegiatan pembelajaran.

Teori peran merupakan perpaduan antara disiplin ilmu sosiologi, antropologi dan psikologi. Ketiga bidang ini harus mampu menjalankannya dengan baik dalam bersikap. Setiap individu 
dalam bersikap dan berperilaku dalam kehidupan sehari-hari sesuai dengan peran yang dimiliki (Sarwono, 2010). Dalam artian disini berarti jika memiliki peran orang tua berarti harus mampu untuk bertindak dan berperilaku sesuai dengan kewajiban yang dimiliki. Seperti halnya mendidik dan mengajarkan kebaikan pada anaknya.

Kegiatan pemahaman pembelajaran daring dilaksanakan dengan tertib dan aman. Peserta memahami materi yang diberikan dan antusias dalam kegiatan tersebut. Kegiatan yang dilakukan sesuai dengan protocol kesehatan. Sebelum kegiatan berlangsung, peserta mencuci tangan terlebih dahulu, dan masuk ke ruangan dengan menggunakan masker serta jaga jarak dalam berkomunikasi. Selain itu, peserta yang mengikuti kegiatan ini terdiri dari 33 orang. Yang mana jumlah tersebut sudah mewakili orang tua di desa Cikuya. Peserta tersebut terdiri dari orang tua yang memiliki anak usia sekolah, guru TK dan guru SD.

2. Pendampingan Orang Tua terhadap Proses Belajar Anak selama Masa Pandemi Covid 19 Pemahaman terkait pembelajaran daring sudah dipahami oleh peserta, setelah itu perlu dilakukannya pendampingan sebagai evaluasi dalam melaksanakan kegiatan pengabdian. Pendampingan orang tua terhadap proses belajar anak selama masa pandemi covid 19 dilakukan dengan memberikan pemahaman terkait dengan pembelajaran daring. Hal ini dimaksudkan untuk memudahkan orang tua dalam memahami pembelajaran daring. Selain itu, agar orang tua dapat melaksanakan pembelajaran daring dengan baik dan dapat meningkatkan pengajaran kepada anaknya.

Kegiatan sosialisasi yang dilaksanakan berjalan dengan baik dan tertib. Peserta berasal dari orang tua, guru TK dan guru SD. Dengan adanya peserta tersebut memudahkan persepsi dan pemahaman bagi orang tua dalam mendidik dan mengajar anaknya. Berkaitan dengan hal tersebut, hal ini juga untuk meningkatkan kualitas dari sumberdaya manusia, dilihat dari guru, peserta didik dan orang tua.

Pendampingan ini dimaksudkan agar diterapkan dalam kehidupan sehari-hari sehingga dalam melaksanakan pembelajaran daring tidak mendapatkan kendala. Baik oleh guru, peserta didik dan orang tua. Persamaan persepsi ini diperlukan untuk memudahkan peserta didik dalam belajar. Sehingga tidak terjadinya keributan antara orang tua dan peserta didik. Bentuk pendampingan ini dengan memberikan motivasi kepada guru, peserta didik dan orang tua agar lebih baik dalam melaksanakan pembelajaran daring. Kegiatan pendampingan pembelajaran daring dapat ditujukan pada Gambar 2.

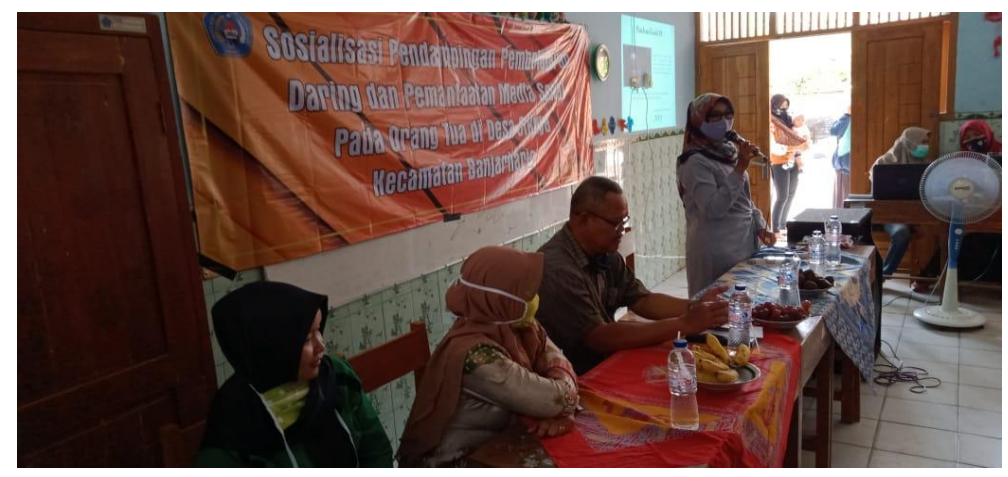

Gambar 2. Pendampingan Pembelajaran Daring

\section{KESIMPULAN}

Kesimpulan dari kegiatan sosialisasi pendampingan pembelajaran daring adalah orang tua, guru SD dan guru TK dapat mengikuti sosialisasi terkait dengan pembelajaran daring dengan baik dan tertib. Orang tua, guru SD dan guru TK dapat memahami materi pembelajaran daring. 
Selain itu orang tua, guru SD dan guru TK dapat menerapka kegiatan pembelajaran daring di rumah.

\section{DAFTAR PUSTAKA}

Ardiansyah, A., \& Arda, A. (2020). Peran Orang Tua Dalam Proses Belajar Anak Di Masa Pandemi Covid-19 Dalam Menumbuhkan Sikap Ilmiah. Musawa, Journal For Gender Studies, 12(1), 140-164. https://doi.org/https://doi.org/10.24239/msw.v12i1.592

Gikas, J., \& Grant, M. M. (2013). Mobile computing devices in higher education: Student perspectives on learning with cellphones, smartphones \& social media. Internet and Higher Education, 19, 18-26. https://doi.org/10.1016/j.iheduc.2013.06.002

Handarini, O. I., \& Wulandari, S. S. (2020). Pembelajaran Daring Sebagai Upaya Study From Home ( SFH ) Selama Pandemi Covid 19. Jurnal Pendidikan Administrasi Perkantoran (JPAP), 8(1), 496-503.

Harliana, H., Setiadi, R., Bachri, O. S., Iskandar, K., \& Prasetya, G. (2020). Pemanfaatan ECommerce Terhadap Penjualan Kendang Jimbe Blitar. Jurnal Abdi Masyarakat UMUS (JAMU), l(01), 15-20.

Putria, H., Maula, L. H., \& Uswatun, D. A. (2020). Analisis Proses Pembelajaran Dalam Jaringan (DARING) Masa Pandemi Covid-19 pada Guru Sekolah Dasar. Jurnal Basicedu, 4(4), 861-872. https://doi.org/10.31004/basicedu.v4i4.460

Sarwono, S. W. (2010). Teori-Teori Psikologi Sosial. In PT. Rajagrafindo Persada.

Toharudin, M., Nuroratiwiningsih, L., \& Fitralisma, G. (2020). Pemberdayaan Anak Usia Sekolah Dalam Menumbuhkan Nilai Karakter Melalui Strategi Pembiasaan di PPSA Tegal. JAMU : Jurnal Abdi Masyarakat UMUS, 1(1). 